\title{
HISTAMINERGIC CONTROL OF THE IRIDAL VASOMOTRICITY IN ALBINO RATS
}

\author{
DRAGOȘ CONSTANTIN LUNCĂ ${ }^{1 \#}$, OANA ANDREIA COMAN ${ }^{1 \#}$, HORIA PĂUNESCU ${ }^{1 *}$, \\ CONSTANTIN ȘTEFANI ${ }^{2}$, LAURENȚIU COMAN ${ }^{3}$, ION FULGA ${ }^{1 \#}$ \\ ${ }^{I}$ Department of Pharmacology and Pharmacotherapy, Faculty of Medicine, "Carol Davila" University of Medicine and \\ Pharmacy, Bucharest, Romania \\ ${ }^{2}$ Department of Family Medicine, Faculty of Medicine, "Carol Davila” University of Medicine and Pharmacy, Bucharest, \\ Romania \\ ${ }^{3}$ Department of Physiology, Faculty of Pharmacy, "Carol Davila” University of Medicine and Pharmacy, Bucharest, \\ Romania
}

*corresponding author: phpaunescu@gmail.com

${ }^{\#}$ Authors with equal contribution.

Manuscript received: March 2020

\begin{abstract}
The study aimed to investigate the iridal vasomotricity by conjunctival administration of histamine and $\mathrm{H}_{1}$ or $\mathrm{H}_{2}$ antagonists. With the approval of the Institutional Ethics Committee, the right eyes of rats, divided in 5 groups, were examined for 11 minutes. The substances, administered at 30 and 330 seconds, after the beginning of tests, were distilled water and histamine $2.5 \mathrm{mM}, 5 \mathrm{mM}$, or $10 \mathrm{mM}$ respectively; olopatadine $2.5 \mathrm{mM}$ followed by histamine $10 \mathrm{mM}$; ranitidine $2.5 \mathrm{mM}$ followed by histamine $2.5 \mathrm{mM}$. The measurements of arteries and veins in 10 moments were performed. In the given experimental conditions, the presence of a histaminergic vasodilator tone was shown. In the iridal territory, this tone produced by $\mathrm{H}_{1}$ and $\mathrm{H}_{2}$ receptors was more intense in arteries than in veins. The vasoconstriction observed after histamine administration might be produced by stimulation of histaminergic $\mathrm{H}_{3}$ receptors.
\end{abstract}

\section{Rezumat}

Studiul a investigat vasomotricitatea iriană la administrarea conjunctivală de histamină și antagoniști $\mathrm{H}_{1}$ sau $\mathrm{H}_{2}$. Cu aprobarea Comisiei Instituționale de Etică, 5 grupuri de șobolani, au fost examinați timp de 11 minute, la nivelul ochilor drepți. Substanțele, administrate la 30 și 330 secunde după începerea testelor, au fost apă distilată și histamină $2,5 \mathrm{mM}, 5 \mathrm{mM}$ sau respectiv $10 \mathrm{mM}$; olopatadină $2,5 \mathrm{mM}$ urmată de histamină $10 \mathrm{mM}$; ranitidină $2,5 \mathrm{mM}$ urmată de histamină $2,5 \mathrm{mM}$. S-au efectuat măsurători ale arterelor și venelor în 10 momente. În condițiile experimentale date, s-a arătat prezența unui tonus vasodilatator histaminergic. În teritoriul irian, acest tonus produs de receptorii $\mathrm{H}_{1}$ și $\mathrm{H}_{2}$ a fost mai intens în artere decât în vene. Vasoconstricția observată după administrarea histaminei pare a fi produsă prin stimularea receptorilor histaminergici $\mathrm{H}_{3}$.

Keywords: histamine, olopatadine, ranitidine, $\mathrm{H}_{3}$ receptors

\section{Introduction}

Histamine is a biogenic amine, widespread in plants and animals, with physiological roles as well as pathogenic roles [4, 17]. There are 4 types of histaminergic receptors noted from $\mathrm{H}_{1}$ to $\mathrm{H}_{4}$, each type of receptor being involved in certain functions: $\mathrm{H}_{1}$ receptors are involved in type 1 allergic reactions, $\mathrm{H}_{2}$ receptors in gastric acid secretion, $\mathrm{H}_{3}$ receptors in synaptic transmission and $\mathrm{H}_{4}$ receptors in immunomodulation [7, 22].

The neuro-humoral regulation of the vascular tone in the anterior ocular segment is different from the posterior ocular segment and other extraocular territories [3, 18, 20]. In retinal vessels, only local systems with many active substances are involved. In the choroidal and iridal territories, the vasomotor activity is regulated also, by neurovegetative mechanisms [14, 16]. Numerous vasomotor regulatory mechanisms are described: adrenergic, cholinergic, or non-adrenergic noncholinergic [2, 6, 21, 25].

The experimental data published so far did not present a complete picture of the effects of histamine on the vasomotricity of the anterior ocular segment, in vivo. Most studies used isolated organ experimental models, and a few in vivo models $[1,5,12,20]$. However, regarding the role of the histaminergic system on vascular control of the ocular posterior segment, there are some human studies showing the vasodilating effect of histamine through $\mathrm{H}_{1}$ receptors, more in the choroidal territory than in the retinal territory $[18$, 23, 26].

Research regarding the control of the anterior ocular segment vasomotricity, by exogenously administered histamine in conjunctival instillations, is rarely addressed in experimental studies $[1,12,18,20]$. From an 
experimental point of view, the Wistar albino rats allow an easy observation of the iridal vessels, in vivo.

The aim of the study was the investigation of the iridal vasomotor control by conjunctival administration of histamine and of $\mathrm{H}_{1}$ or $\mathrm{H}_{2}$ antagonists followed by histamine.

\section{Materials and Methods}

Five groups of male albino rats weighing 300 to 350 grams were kept under standard conditions. The animals had free access to water and standardized food, and the experiments were conducted on daylight, from 8 a.m. to 3 p.m. Observations were made only

in the right eye of each rat. The approval of the institutional ethics commission for conducting the experiments was obtained.

The used substances were: Distilled water (Zentiva SA, Romania), Ketamine, 10\% solution (CP-Ketamin $10 \%$, CP-Pharma, Germany, veterinary medicine), Olopatadine, ophthalmic solution $1 \mathrm{mg} / \mathrm{mL}$ (Opatanol ${ }^{\circledR}$ $1 \mathrm{mg} / \mathrm{mL}$, ophthalmic drops, Alcon, United Kingdom) $\mathrm{H}_{1}$ antagonist, Ranitidine, $25 \mathrm{mg} / \mathrm{mL}$ solution for injection (Arnetin ${ }^{\circledR} 50 \mathrm{mg} / 2 \mathrm{~mL}$, solution for injection, Medochemie, Cyprus) - $\mathrm{H}_{2}$ antagonist, Histamine hydrochloride, purity powder $>99 \%$ (Sigma).

Table I

Substances used for each experimental group

\begin{tabular}{|l|c|c|}
\hline & Substance administered at moment $\mathrm{t}_{1}\left(30 \mathrm{sec}\right.$. after $\left.\mathrm{t}_{0}\right)$ & Substance administered at moment $\mathrm{t}_{6}\left(330\right.$ sec. after $\left.\mathrm{t}_{0}\right)$ \\
\hline Group 1 & Distilled water & Histamine $2.5 \mathrm{mM}$ \\
\hline Group 2 & Distilled water & Histamine $5 \mathrm{mM}$ \\
\hline Group 3 & Distilled water & Histamine $10 \mathrm{mM}$ \\
\hline Group 4 & Olopatadine $2.5 \mathrm{mM}$ & Histamine $10 \mathrm{mM}$ \\
\hline Group 5 & Ranitidine $2.5 \mathrm{mM}$ & Histamine $10 \mathrm{mM}$ \\
\hline
\end{tabular}

sec. $=$ seconds, $\mathrm{mM}=$ millimolar

Table II

Timeline - moments of administration of substances $\left(t_{1}\right.$ and $\left.t_{6}\right)$ and recording of vascular diameters $\left(t_{0}, t_{2}, t_{3}, t_{4}, t_{5}\right.$,

\begin{tabular}{|c|c|c|c|c|c|c|c|c|c|c|c|}
\hline $\mathrm{t}_{0}$ & $\mathbf{t}_{1}$ & $\mathrm{t}_{2}$ & $\mathrm{t}_{3}$ & $\mathrm{t}_{4}$ & $\mathrm{t}_{5}$ & $\mathrm{t}_{6}$ & $\mathrm{t}_{7}$ & $\mathrm{t}_{8}$ & $\mathrm{t}_{9}$ & $\left.\mathrm{t}_{8}, \mathrm{t}_{9}, \mathrm{t}_{10}, \mathrm{t}_{11}\right)$ \\
\hline $0 \mathrm{sec}$. & $\mathbf{3 0}$ sec. & $120 \mathrm{sec}$. & $180 \mathrm{sec}$. & $210 \mathrm{sec}$. & $300 \mathrm{sec}$. & $\mathbf{3 3 0}$ sec. & 420 sec. & 480 sec. & 510 sec. & 600 sec. & 630 sec. \\
\hline
\end{tabular}

sec. $=$ seconds

The experimental protocol was described in previously published papers [12]. 15 minutes after the rats were anesthetized with ketamine $10 \%$, we began to record the right eye of each animal. For the image acquisition we used NIKON objective lens, an adapter (NAVITAR $1 \mathrm{X}$ Adapter 1-6015) connected to a CCD camera (TOSHIBA-IK642E), a Logilink video-grabber analogto-digital converter USB 2.0 and a circular cold light source (Dolan-Jenner Industries Inc. FiberLite Series 180). For each analysed eye, the recording lasted 11 minutes and the substances were administered by conjunctival instillations at 30 seconds, respectively 330 seconds after the beginning of the recording (Table I and Table II). For each eye, image captures were made at specific moments (Table II).

The measurements were made near the point of crossing between an artery and a vein, the smaller vessel located in front being considered an artery, and the larger vessel located posteriorly being considered a vein. The measurements were made in pixels. The diameter was measured using images in grayscale in the program Image J, plug-in Diameter (Figures 1A and 1B).

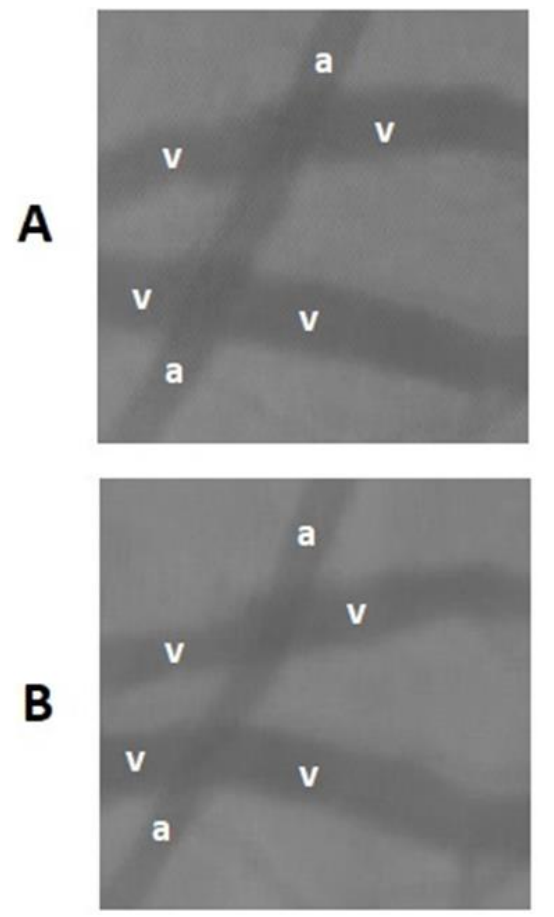

Figure 1.

A. An artery and a vein in the initial moment $\left(\mathrm{t}_{0}\right)$. The artery is the smaller vessel situated anterior than veins with a thicker wall. B. Vasoconstriction in the artery registered at $\mathrm{t}_{4}-210 \mathrm{sec}$. after the moment $\mathrm{t}_{0}$, the administration of ranitidine being made at $t_{1}-30 \mathrm{sec}$. 
In order to mitigate the interindividual variations between rats, the actual diameters measured in pixels were not taken into consideration. Instead, the percentage variations of the vascular diameters found at each moment of determination, relative to the moment $t_{0}$ for each individual animal was calculated and statistically analysed. We used the formula: $D_{\text {rel }}=$ $100 \times\left(D_{x}-D_{0}\right) / D_{0}$, where $D_{\text {rel }}$ is the relative diameter change in relation to moment $t_{0}, D_{x}$ is the diameter of the vessel measured in pixels at the moment of measurement $\left(\mathrm{t}_{\mathrm{x}}\right)$ and $\mathrm{D}_{0}$ is the vessel's diameter measured in pixels at the moment $t_{0}$. Based on these values, for each group the average values and standard errors were calculated for each moment of determination. Student's t-test was used for statistical analysis, "paired" variant, and differences were considered significant if $\mathrm{p}<0.05$.

\section{Results and Discussion}

For the first 3 groups, the effect of exogenous histamine on the iridal vascular diameter was evaluated. The histamine concentrations used were in geometrical progression with common ratio 2 (Figures $2 \mathrm{~A}$ and $2 \mathrm{~B}$ ). Results obtained after administration of histamine 10 $\mathrm{mM}\left(\mathrm{t}_{6}\right)$ after olopatadine $2.5 \mathrm{mM}\left(\mathrm{t}_{1}\right)$ for group 4 are shown in Figure 3A (iridal arterial diameters) and Figure 3B (iridal venous diameter). Results obtained after administration of histamine $10 \mathrm{mM}\left(\mathrm{t}_{6}\right)$ after ranitidine $2.5 \mathrm{mM}\left(\mathrm{t}_{1}\right)$ for group 5 are shown in Figure 4A (iridal arterial diameters) and Figure 4B (iridal venous diameter).

This paper aimed to study the role of histamine in controlling the iridal vascular tone. Essentially, it was based on a few working principles. First, it was considered that if an autacoid influences vascular motility, it is imperative that iridal vessels contain receptors for that autacoid; if such receptors exist, they may also be stimulated by the autacoid exogenously administered. Second, since most autacoids act through several subtypes of specific receptors, the study aimed to determine how much the blocking of different subtypes of receptors with specific antagonists might influence the effect of the investigated substance. Third, theoretical considerations have been made regarding the extent at which the endogenous autacoids perform phasic or tonic control in the iridal vessels. It was considered that if the administration of a blocker produces an inverse effect, then the autacoid performs a tonic control. If the administration of a blocker has no effect, but the blocker antagonizes the effect of the autacoid administered topically, then the autacoid exerts a phasic control [12].

The changes in the iridal vessels (arteries and veins) diameters following the administration of histamine without and with $\mathrm{H}_{1}$, respectively $\mathrm{H}_{2}$ receptor blockade, in rats were studied.
In the first 3 groups of animals, histamine was administered by conjunctival instillations, in concentrations that were in geometrical progression with common ratio 2: $2.5 \mathrm{mM}, 5 \mathrm{mM}$ and $10 \mathrm{mM}$. Histamine produced vasoconstriction in the iridal arteries, but only at the maximum concentration used $(10 \mathrm{mM})$, without affecting the size of the iridal veins. These results may show that at least iridal arteries have histaminergic receptors whose stimulation by exogenous histamine produces constriction. The lack of effect of histamine was not considered an argument in favour of the hypothesis that there are no histaminergic receptors in the iridal veins.

A

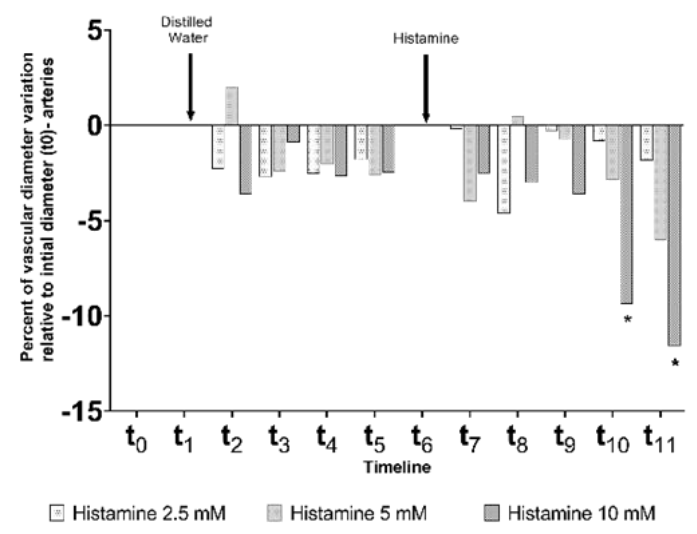

B

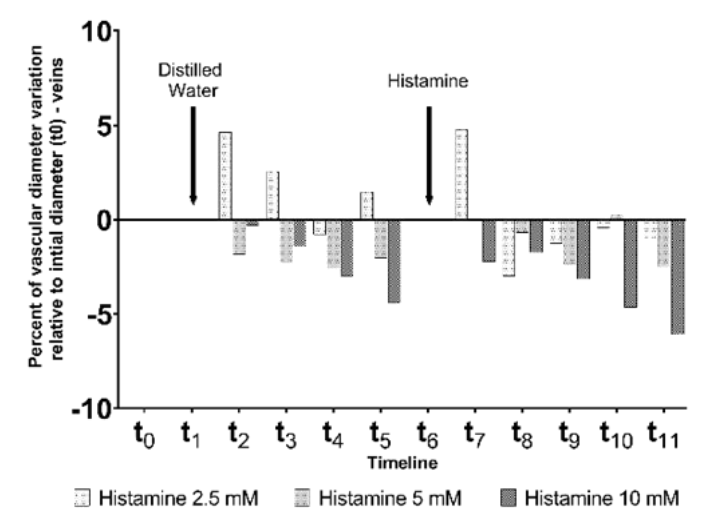

Figure 2.

Evolution of iridal arterial (A) and venous (B) diameters in group 1 (histamine $2.5 \mathrm{mM}$ ), group 2 (histamine $5 \mathrm{mM}$ ), group 3 (histamine $10 \mathrm{mM}$ ), respectively, after administration of distilled water at moment $\mathrm{t}_{1}(30 \mathrm{~s})$ and after histamine, at moment $t_{6}(330 \mathrm{~s})$. The moments at which the vessel diameters were evaluated, in percentage relative to the initial diameter $\left(\mathrm{t}_{0}\right)$, are presented on the abscissa. $* \mathrm{p}<0.05$ vs. $\mathrm{t}_{0}$ value. 
A

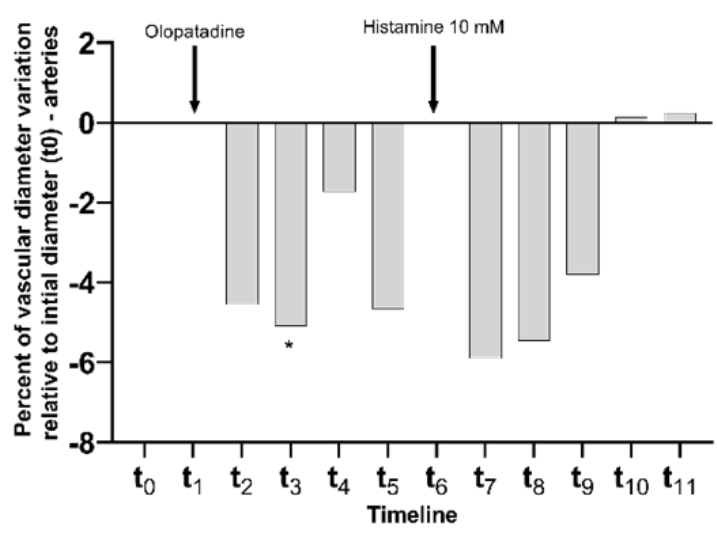

B

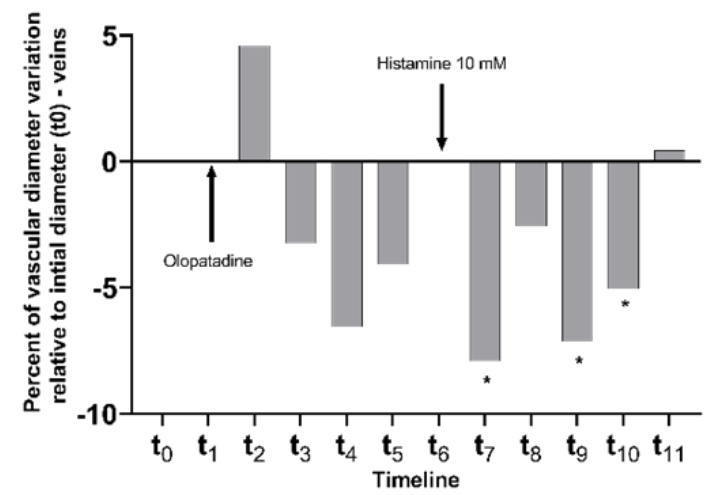

Figure 3.

Evolution of the iridal arterial (A) and venous (B) diameters, after administration of olopatadine 2.5 $\mathrm{mM}$ at moment $\mathrm{t}_{1}$ and after histamine $10 \mathrm{mM}$, at moment $t_{6}$. The moments at which the vessel diameters were evaluated, in percentage relative to the initial diameter $\left(t_{0}\right)$, are presented on the abscissa. $* \mathrm{p}<0.05$ vs. $\mathrm{t}_{0}$ value.

The administration of olopatadine produced arterial constriction, suggesting the existence of a vasodilator histaminergic tone that is produced by $\mathrm{H}_{1}$ receptors in the iridal arteries. Histamine administration after olopatadine did not produce statistically significant changes in the arteries diameters. Theoretically, histamine administration after olopatadine would increase the arterial constriction produced by endogenous histamine; but this phenomenon did not occur. This made us assume that the vasoconstrictor histaminergic tone might be so high that the amount of exogenous histamine could not exceed this tone. This assertion is in agreement with the fact that the vasoconstriction produced by histamine was, however, of low intensity about $10 \%$ - and it was produced only by the maximum concentration of histamine used $(10 \mathrm{mM})$. The existence of a high vasoconstrictor histaminergic tone in the iridal arteries might be supposed.
A

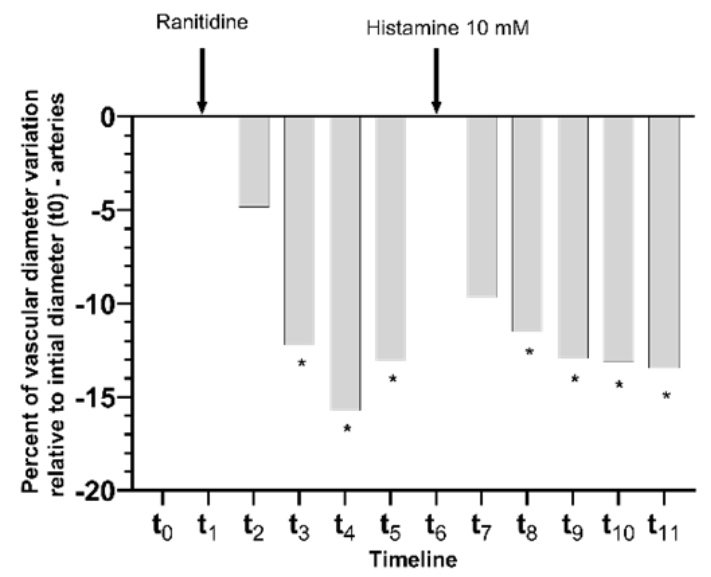

B

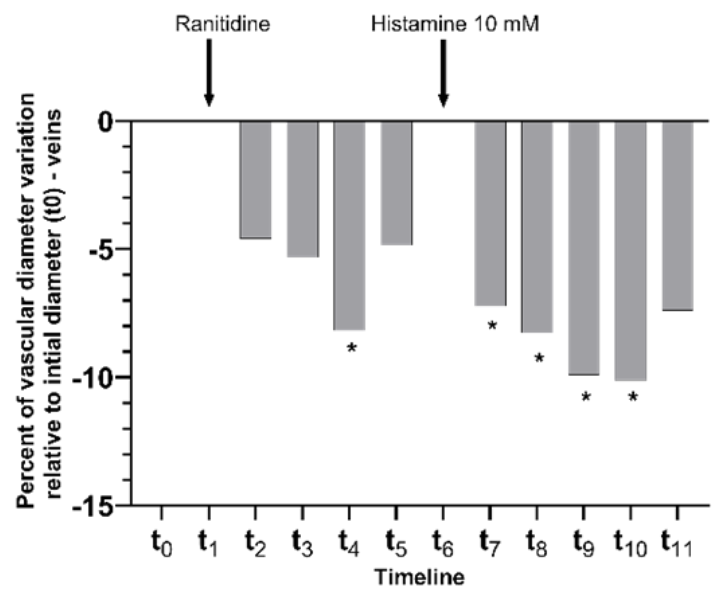

Figure 4.

Evolution of the iridal arterial (A) and venous (B) diameter, after administration of ranitidine $2.5 \mathrm{mM}$ at moment $\mathrm{t}_{1}$ and after histamine $10 \mathrm{mM}$, at moment $\mathrm{t}_{6}$. The moments at which the vessel diameters were evaluated, in percentage relative to the initial diameter $\left(\mathrm{t}_{0}\right)$, are presented on the abscissa. ${ }^{*} \mathrm{p}<0.05 \mathrm{vs} . \mathrm{t}_{0}$ value.

Olopatadine did not change the diameter of the iridal veins, but the administration of histamine after olopatadine produced a statistically significant venous constriction. This might show that the iridal veins have a less intense vasodilatory histaminergic tone than the iridal arteries, tone produced by the $\mathrm{H}_{1}$ receptors.

Ranitidine produced statistically significant vasoconstriction in both arterial and venous iridal territories, suggesting the existence of a vasodilator histaminergic tone produced by $\mathrm{H}_{2}$ receptors. The administration of histamine after ranitidine also produced vasoconstriction, both in the iridal arteries and veins. There is a vasodilatory $\mathrm{H}_{2}$ histaminergic tone both in arteries and veins.

Under these conditions, the only logical assumption seemed to be that exogenous histamine produced vaso- 
constriction through a different type of histaminergic receptor rather than $\mathrm{H}_{1}$ or $\mathrm{H}_{2}$ receptors.

Other types of histaminergic receptors, namely the $\mathrm{H}_{3}$ receptors and the $\mathrm{H}_{4}$ receptors, are described in the literature. The most studied are the $\mathrm{H}_{3}$ receptors, which are present in the cardiovascular system [13]. They act as a presynaptic receptor whose stimulation decreases the release of specific biologically active substances, including histamine, dopamine, serotonin and possibly noradrenaline [8].

The affinity of histamine for $\mathrm{H}_{3}$ receptors is higher than that for $\mathrm{H}_{1}$, respectively $\mathrm{H}_{2}$ receptors [11]. Also, $\mathrm{H}_{3}$ receptors are described in the iris [10]. Histamine might produce $\mathrm{H}_{3}$-mediated vasoconstriction. $\mathrm{H}_{3}$ receptors, acting as presynaptic receptors, might decrease the release of endogenous histamine that can stimulate postsynaptic $\mathrm{H}_{1}$ and $\mathrm{H}_{2}$ receptors and thus indirectly might inhibit the vasodilatory effects due to endogenously released histamine [7, 9, 19].

These theoretical speculations could be confirmed by the in vivo administration of $\mathrm{a}_{3}$ receptor antagonist which could reveal the vasodilatory effect of histamine (a phenomenon that has a possible $\mathrm{H}_{1}$ or $\mathrm{H}_{2}$ stimulation component).

The histaminergic system, along with other biological systems, may have larger unexplored roles in various eye diseases, such as glaucoma, dry eye disease, ocular tumorigenesis, ocular vascular disease $[15,24]$.

\section{Conclusions}

Histamine in a concentration of $10 \mathrm{mM}$ administered in rats by conjunctival instillations produced iridal arterial, but not iridal venous constriction.

The administration of olopatadine produced arterial constriction and ranitidine produced statistically significant vasoconstriction in both arterial and venous iridal territories.

A vasodilatory histaminergic tone produced by $\mathrm{H}_{1}$ and $\mathrm{H}_{2}$ receptors might be present in iridal vascular territory and is more intense in arteries than in veins. Vasoconstriction observed after histamine administration might be produced by stimulation of histaminergic $\mathrm{H}_{3}$ receptors.

\section{Conflict of interest}

The authors declare no conflict of interest.

\section{References}

1. Bielory L, Ghafoor S, Histamine receptors and the conjunctiva. Curr Opin Allergy Clin Immunol., 2005; 5(5): 437-440.

2. Bill A, Nilsson SF, Control of ocular blood flow. $J$ Cardiovasc Pharmacol., 1985; 7(Suppl 3): S96-S102.

3. Buckley CH, Hadoke PW, O'Brien CJ, Use of isolated ocular arteries in vitro to define the pathology of vascular changes in glaucoma. Br J Ophthalmol., 1997; 81(7): 599-607.
4. Cataldi M, Borriello F, Granata F, Annunziato L, Marone G, Histamine receptors and antihistamines: from discovery to clinical applications. Chem Immunol Allergy, 2014; 100: 214-226.

5. Coman L, Coman OA, Păunescu H, Drăghia F, Fulga I, VEGF-induced corneal neovascularisation in a rabbit experimental model. Rom J Morphol Embryol., 2010; 51(2): 327-336.

6. Constantin M, Șerban DN, Pricop C, Huzum B, Șerban IL, Extracellular $\mathrm{Mg}^{2+}$ level affects the major mechanism of endothelium-dependent relaxation in resistance arteries. Farmacia, 2019; 67(5): 888-891.

7. Ebeigbe AB, Talabi OO, Vascular Effects of Histamine. Niger J Physiol Sci., 2014; 29(1): 7-10.

8. Esbenshade TA, Browman KE, Bitner RS, Strakhova M, Cowart MD, Brioni JD, The histamine $\mathrm{H}_{3}$ receptor: an attractive target for the treatment of cognitive disorders. Br J Pharmacol., 2008; 154(6): 1166-1181.

9. Kyriakidis K, Zampeli E, Palaiologou M, Tiniakos D, Tiligada E, Histamine $\mathrm{H}_{3}$ and $\mathrm{H}_{4}$ receptor ligands modify vascular histamine levels in normal and arthritic large blood vessels in vivo. Inflammation, 2015; 38(3): 949-958.

10. Lanzi C, Lucarini L, Durante M, Sgambellone S, Pini A, Catarinicchia S, Lazewska D, Kiec-Kononowicz K, Stark H, Masini E, Role of Histamine $\mathrm{H}_{3}$ Receptor Antagonists on Intraocular Pressure Reduction in Rabbit Models of Transient Ocular Hypertension and Glaucoma. Int J Mol Sci., 2019; 20(4): 981: 1-15.

11. Ligneau X, Morisset S, Tardivel-Lacombe J, Gbahou F, Ganellin CR, Stark H, Schunack W, Schwartz JC, Arrang JM, Distinct pharmacology of rat and human histamine $\mathrm{H}(3)$ receptors: role of two amino acids in the third transmembrane domain. Br J Pharmacol., 2000; 131(7): 1247-1250.

12. Luncă DC, Păunescu H, Mușat O, Fulga I, The histaminergic control of the iridal vascular tone in rats and its influencing by topical administration of olopatadine and ranitidine. Rom J Ophthalmol., 2019; 63(1): 23-28.

13. Malinowska B, Godlewski G, Schlicker E, Histamine $\mathrm{H}_{3}$ receptors--general characterization and their function in the cardiovascular system. J Physiol Pharmacol., 1998; 49(2): 191-211.

14. McDougal DH, Gamlin PD, Autonomic control of the eye. Compr Physiol., 2015; 5(1): 439-473.

15. Mehta P, Miszta P, Rzodkiewicz P, Michalak O, Krzeczyński P, Filipek S, Enigmatic histamine receptor $\mathrm{H}_{4}$ for potential treatment of multiple inflammatory, autoimmune, and related diseases. Life (Basel), 2020; 10(4): 50: 1-17.

16. Neuhuber W, Schrödl F, Autonomic control of the eye and the iris. Auton Neurosci., 2011; 165(1): 67-79.

17. Parsons ME, Ganellin CR, Histamine and its receptors. Br J Pharmacol., 2006; 147(Suppl 1): S127-S135.

18. Resch H, Zawinka C, Lung S, Weigert G, Schmetterer L, Garhöfer G, Effect of histamine and cimetidine on retinal and choroidal blood flow in humans. Am J Physiol Regul Integr Comp Physiol., 2005; 289(5): R1387-R1391.

19. Schwartz JC, The histamine $\mathrm{H}_{3}$ receptor: from discovery to clinical trials with pitolisant. $\mathrm{Br} J$ Pharmacol., 2011; 163(4): 713-721. 
20. Su E, Yu D, Cringle S, Histamine induces opposing vasoactive effects at different levels of the ocular vasculature. Curr Eye Res., 2005; 30(3): 205-212.

21. Toda M, Okamura T, Ayajiki K, Toda N, Neurogenic vasoconstriction as affected by cholinergic and nitroxidergic nerves in dog ciliary and ophthalmic arteries. Invest Ophthalmol Vis Sci., 1999; 40: 17531760.

22. Wade L, Bielory L, Rudner S, Ophthalmic antihistamines and $\mathrm{H}_{1}-\mathrm{H}_{4}$ receptors. Curr Opin Allergy Clin Immunol., 2012; 12(5): 510-516.

23. Weigert G, Zawinka C, Resch H, Schmetterer L, Garhöfer G, Intravenous administration of diphenhydramine reduces histamine-induced vasodilator effects in the retina and choroid. Invest Ophthalmol Vis Sci., 2006; 47(3): 1096-1100

24. Xu W, Lv Q, Liu Y, Lai X, Liu F, Tu G, Homology model, docking analysis and molecular dynamics simulation of cannabinoid CB2 receptor. Farmacia, 2020; 68(2):362-368.

25. Yoshitomi T, Ishikawa H, Hayashi E, Pharmacological effects of pilocarpine on rabbit ciliary artery. Curr Eye Res., 2000; 20(4): 254-259.

26. Zawinka C, Resch H, Schmetterer L, Dorner GT, Garhofer G. Intravenously administered histamine increases choroidal but not retinal blood flow. Invest Ophthalmol Vis Sci., 2004; 45(7): 2337-2341. 